
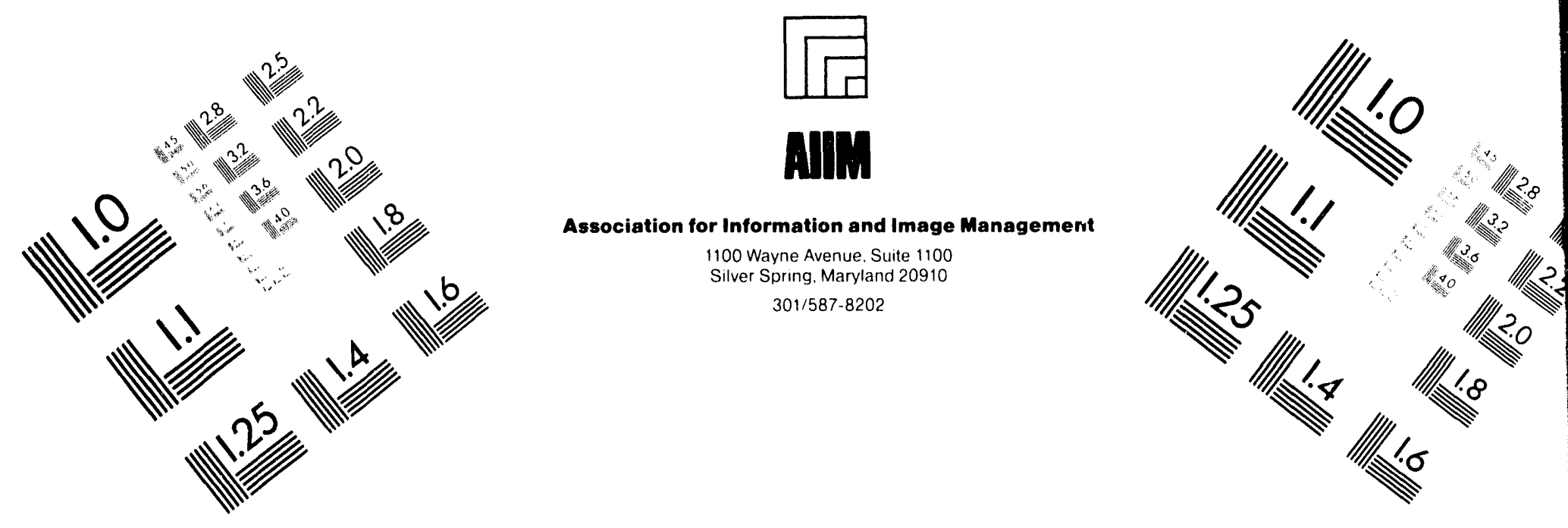

Centimeter

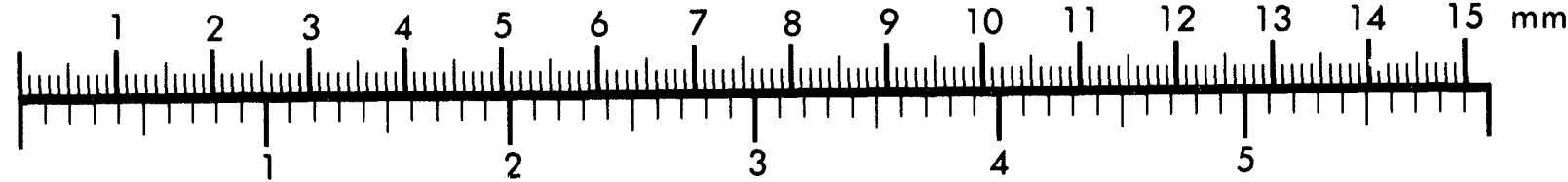
Inches
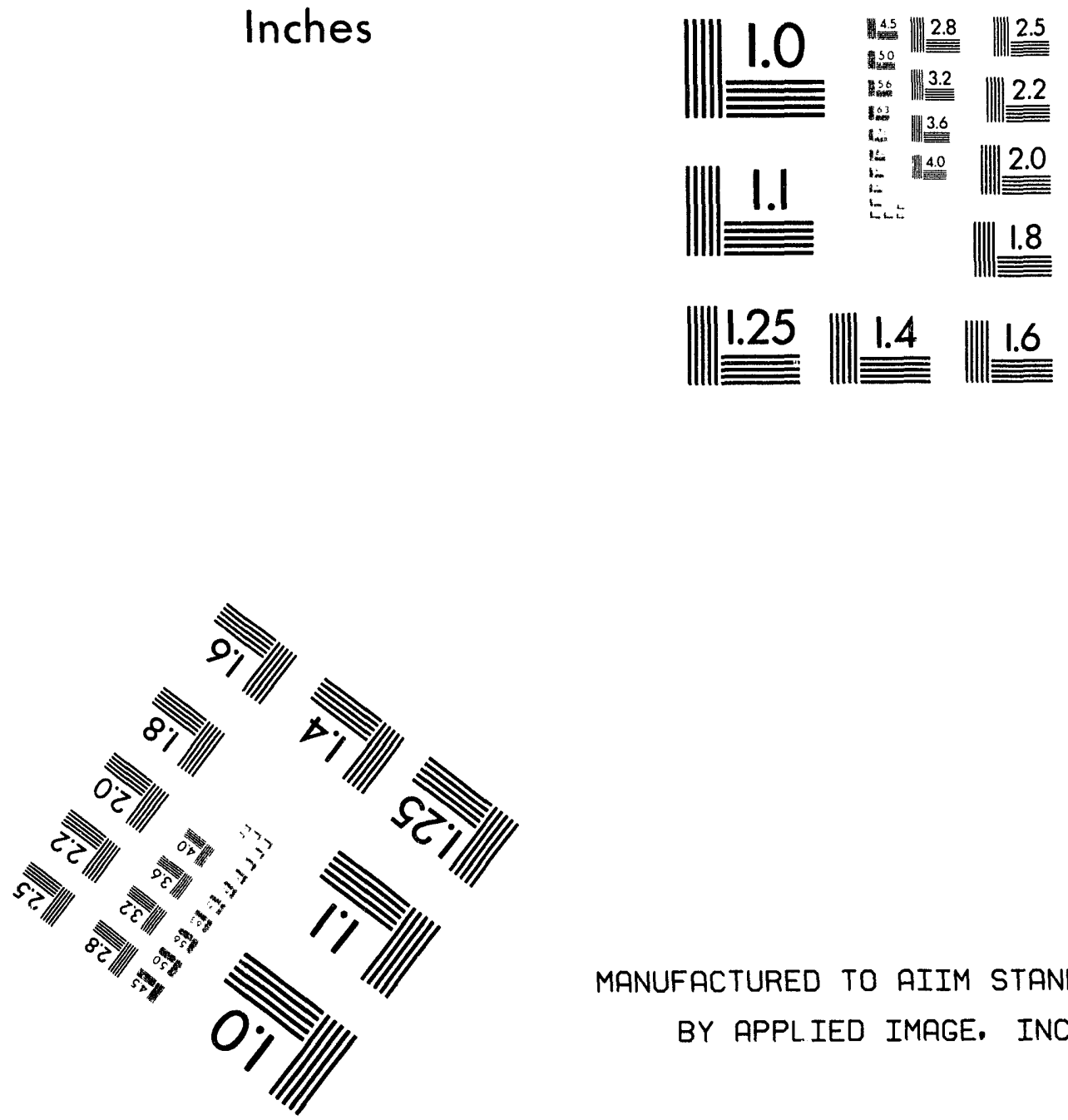

MANUFACTURED TO AIIM STANDARDS

BY APPLIED IMAGE. INC.

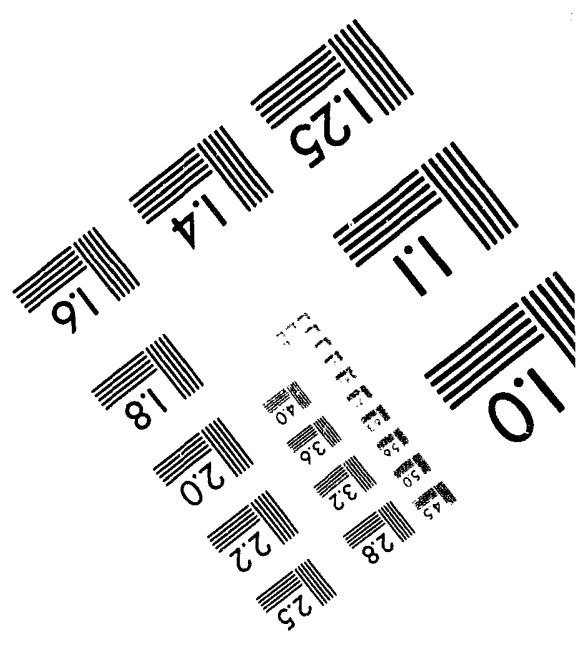



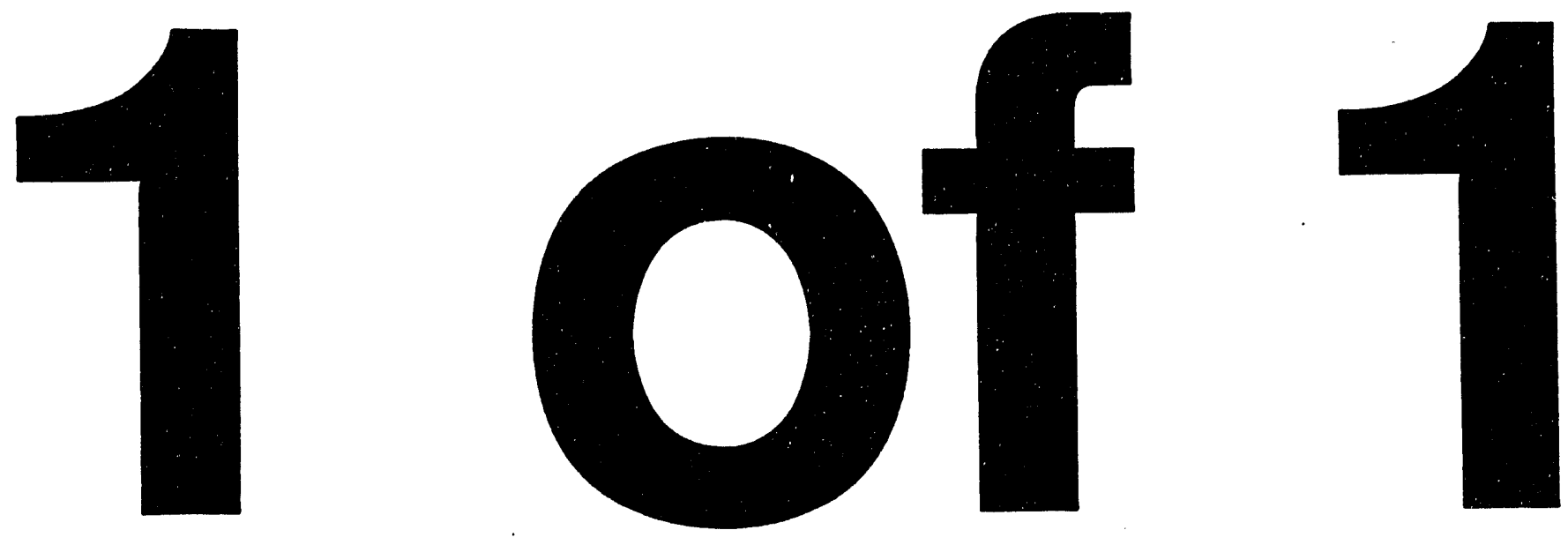


\title{
MANAGEMENT OF RADIOACTIVE WASTE FROM NUCLEAR POWER PLANTS AN OVERVIEW*
}

\author{
Jas S. Devgun \\ Office of Waste Management Programs \\ Argonne National Laboratory \\ 9700 South Cass Avenue \\ Argonne, IL 60439
}

\author{
For presentation at \\ 29th Intersociety Energy Conversion Engineering Conference \\ "Energy Conversion-Investment in America" \\ Monterey, CA \\ August 7-12, 1994
}

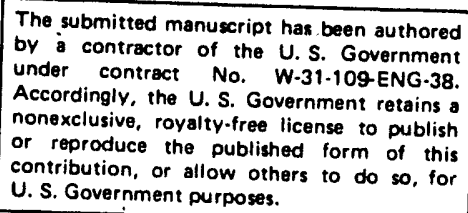

The submitted manuscript has been authored by a contractor of the U.S. Government under contract No. W-31.109-ENG-38. Accordingly, the $U . S$. Government retains. nonexclusive, royalty free license to publish or reproduce the published iorm contribution, or allis U. S Government purpers to do so, for U. S. Government purposes.

\section{DISCLAIMER}

This report was prepared as an account of work sponsored by an agency of the United States Government. Neither the United States Government nor any agency thereof, nor any of their employees, makes any warranty, express or implied, or assumes any legal liability or responsibility for the accuracy, completeness, or usefulness of any information, apparatus, product, or process disclosed, or represents that its use would not infringe privately owned rights. Reference herein to any specific commercial product, process, or service by trade name, trademark, manufacturer, or otherwise does not necessarily constitute or imply its endorsement, recommendation, or favoring by the United States Government or any agency thereof. The views and opinions of authors expressed herein do not necessarily state or reflect those of the United States Government or any agency thereof.

"Work supported by the Office of Technology Development within the U.S.Department of Energy's Office of Environmental Management, under contract W-31-109-ENG 38.

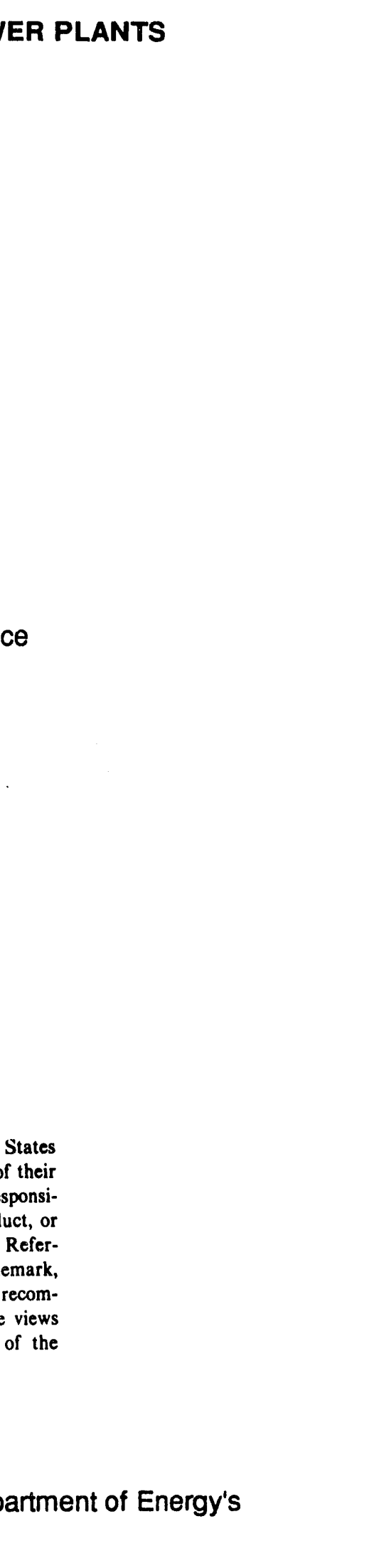

RECEIVED 


\title{
MANAGEMENT OF RADIOACTIVE WASTE FROM NUCLEAR POWER PLANTS: AN OVERVIEW*
}

\author{
Jas S. Devgun, Ph.D. \\ Office of Waste Management Programs \\ Argonne National Laboratory \\ 9700 South Cass Avenue \\ Argonne, IL 60439
}

\begin{abstract}
The nuclear power industry, which accounts for about $20 \%$ of the total electricity supply, is a vital part of the nation's energy resource. While it generates approximately one-third of the commercial low-level radioactive waste produced in the country, it has achieved one of the most successful examples in waste minimization. On the other hand, progress on development of new disposal facilities by the state compacts is currently stalled. The milestones have been repeatedly postponed, and the various Acts passed by Congress on nuclear waste disposal have not accomplished what they were intended to do. With dwindling access to waste disposal sites and with escalating disposal costs, the power plant utilities are forced to store wastes onsite as an interim measure. However, such temporary measures are not a permanent solution. A national will is sorely needed to break out of the current impasse.
\end{abstract}

\section{INTRODUCTION}

The 112 operable nuclear power plants in the United States account for about 35\% of the nondefense related low-level radioactive waste (LLW) volume generated each year and nearly all of the commercial spent fuel.

With disposal costs rising sharply, and with increasingly restrictive regulations, the nuclear power industry has reduced the annual volume of LLW shipped for disposal per reactor to approximately one-fifth the volume that was

\footnotetext{
"Work supported by the Office of Technology Development within the U.S.Department of Energy's Office of Environmental Management, under contract W-31-109-ENG 38.
}

shipped per reactor about a decade ago. The industry has made concerted efforts at waste source reduction and uses a number of technologies to reduce the volume of solid and liquid wastes.

After compacting, most of the solid LLW is shipped directly to disposal facilities, primarily the Barnwell, SC, site, even though some utilities are now using interim on-site storage. The spent nuclear fuel, on the other hand, is destined to stay in wet or dry storage facilities until the federal facility at Yucca Mountain site becomes a reality, which may be two decades or more away.

Legislative initiatives at the congressional level, in the form of the Low-Level Radioactive Waste Policy Act of 1980, (and its 1985 Amendment) placed the responsibility of management of such wastes on the states. However, the progress towards new facility development has been dismal and no new disposal sites may open in the near future. The nuclear power industry is, thus, faced with dwindling access to waste disposal sites and escalating costs of managing such wastes.

This paper will provide an overview of the radioactive waste from the nuclear power industry from its generation to disposal.

\section{WASTE TYPES}

Primarily two types of wastes are generated at the nuclear power plants:
1. Spent fuel
2. Low-level radioactive waste

Typically, about one-third of the nuclear fuel inside a reactor core is annually removed and replaced with fresh fuel. The spent fuel is highly radioactive and requires radiation shielding as well as thermal cooling.

The low-level radioactive waste covers a wide 
variety of wastes and a wide spectrum of activity levels. In fact, what are classified as intermediate-level wastes in the international terminology are part of the low-level waste in the U.S. classification. This classification is promulgated by the U.S. Nuclear Regulatory Commission's 10 CFR 61, Licensing Requirements for Land Disposal of Radioactive Waste, where the detailed definitions are also available based on the concentrations of longlived and short-lived radionuclides, other waste characteristics, and the stability requirements. The waste classes are:

\section{- Class A, Class B, or Class C - Greater than Class C}

In general, Class A waste can be disposed of directly as long as meets certain waste characteristics and stability requirements. Class $B$ waste must meet more rigorous requirements on waste stability; Class C waste additionally requires protection against inadvertent intrusion. The U.S. Department of Energy (DOE) is responsible for the disposal of greater-than- Class $\mathrm{C}$ waste. It is worth noting that the Class A waste comprises about $96 \%$ of all the low-level waste received at commercial disposal facilities, followed by Class $B$ at about $2.5 \%$, and Class $C$ at $1.5 \%$.

\section{SPENT FUEL}

Most of the spent fuel is stored at reactor sites in pools of water. But, because the available pool storage space at many power plants is now limited, dry cask storage is coming into more common use. A total of about 20,000 tons of spent fuel is currently stored in wet or dry storage facilities across thie country. Pool storage or dry cask storage is, nevertheless, only a temporary solution because the spent fuel will remain highly radioactive and hazardous for several thousand years. Thus, there is a critical need for a permanent disposal facility in the long term.

The Nuclear Waste Policy Act (NIWPA) of 1982 required utilities to provide for storage of spent fuel though 1998. Under this Act the DOE is supposed to accept spent fuel from power reactors by January 31,1998 . For several years now, the DOE has been characterizing the Yucca Mountain site in Nevada as the disposal site for spent fuel and high-level waste originating from the nation's defense programs. The concept calls for building an engineered facility about $1,000 \mathrm{ft}$ underground in the Yucca Mountain tuff; the repository and its engineered barrier system are expected to isolate the waste for 10,000 years. However, even under the most optimistic scenario, the Yucca Mountain repository will not be ready to receive shipments of spent fuel by the year 2010 . In the meanwhile, the pool storage at many reactor sites is nearing capacity. The DOE has recognized that it may not meet the milestone of accepting spent fuel by 1998 and has indicated a willingness to help utilities use multipurpose canisters (MPC) for dry storage of spent fuel. Such containers can be used to store, transport, and bury waste.

With no high-level waste disposal facility in sight for at least two decades, and with uncertainty as to whether DOE will be able to accept spent fuel by the scheduled date (even at an interim facility), the utilities are in a bind to find alternatives for storing spent fuel. Hence, more and more utilities are exercising the option of dry cask storage of spent fuel. Currently, such facilities are in operation at the following sites: Consumer Power's Palisades Station, Virginia Fower's Surry Dry Storage Facility, Carolina Power and Light's Robinson 2, Duke Power Company's Oconee Station, Public Service Company of Colorado's Fort St. Vrain Station (Modular Vault Dry Storage), and Baltimore Gas and Electric's Calvert Cliffs.

\section{LOW-LEVEL RADIOACTIVE WASTE}

The LLW can be in the physical form of solid, liquid, or gas. From operational perspective, the LLW in the power plant industry is categorized as:

$\begin{array}{ll}\text { - } & \text { Dry Active Waste (DAW) } \\ \text { - } & \text { Wet Waste } \\ & \text { Liquid Waste }\end{array}$

The bulk of the LLW is in the form of dry active waste; wet waste can also be generally dewatered. Approximately $96 \%$ of the solid LLW generated at nuclear power plants is Class A under 10 CFR 61 classification, with approximately $3 \%$ Class $B$, and $1 \%$ or less Class C. The liquid wastes originate from a number of sources, including reactor coolant systems, auxiliary systems, laboratory drains, floor drains, decontamination, and laundry among others. 
Both Pressurized Water Reactors (PWRs) and Boiling Water Reactors (BWRs) produce gaseous waste containing radionuclides in the form of noble gases ( $\mathrm{Xe}-133$ and $\mathrm{Kr}-85$ ), activation products (such as $\mathrm{N}-13, \mathrm{C}-14, \mathrm{~N}-16, \mathrm{~N}-17, \mathrm{O}-19$, $\mathrm{F}-18$ ), radioiodines, and tritium. In a PWR, sources of gaseous waste include the volume control tank, reactor coolant drain tank, gas stripper, cover gases, and pressurizer relief tank. A BWR generates much larger volumes primarily as off-gases from the condenser; other sources in a BWR include the turbine steam seal system and mechanical vacuum pump system exhaust. The BWR units use recombiner charcoal adsorber systems, or cryogenic distillation systems as well as standby gas treatment systems (for emergency use). The PWR units use gaseous waste processing systems using catalytic recombination following a compressing pretreatment step. Except for the basic description above, gaseous waste management is not discussed further. The emphasis in this paper is on the solid and liquid low-level waste.

\section{Waste Characteristics}

While the characteristics of the waste originating from PWRs and BWRs differ, the key radionuclides in LLW (DAW and wet solids) include $\mathrm{Fe}-55$, Co-60, Ni-63, Cs-134, Cs-137, Sr90, I-129, C-14, and Tc-99. On an industry-wide average basis, $\mathrm{Fe}-55$ accounts for the bulk of the activity in dry active waste. In PWR waste, the average activity percentages are: $\mathrm{Fe}-55(39 \%)$, Co-60 (18\%), Cs-137 (16\%), Ni-63 (15\%), and Cs-134 (12\%); for BWR waste these levels are: $\mathrm{Fe}-55(62 \%), \mathrm{Co}-60(20 \%), \mathrm{Cs}-137$ (8\%), Ni-63 $(8 \%)$, and Cs-134 (2\%).

The DAW consists of protective clothing, plastics, paper, cloth, adsorbent materials, metals, wood, tools, concrete, and other miscellaneous items. Wet solid waste consists of resins, filters, evaporator bottoms, and sludges. Such wastes can be dewatered, and technologies for dry waste processing can then be applied.

The concentrations of radionuclides found in the liquid waste streams from PWRs and BWRs vary, depending upon a number of variables such as reactor's power history, fuel burnup, impurities and additives in coolant systems, integrity of fuel cladding, and rate of coolant purification. The radionuclides include: $\mathrm{H}-3, \mathrm{Co}-60, \mathrm{Co}-58$, Cs-
137, Cs-134, Sr-90, C-14, Mn-54, Cr-51, Fe-59, and $\mathrm{Zn}-65$ among others.

\section{Volume Reduction}

Steep increases in disposal cost and the dwindling access to disposal sites have necessitated extensive use of volume reduction technologies. These technologies include: evaporation, distillation, crystallization, precipitation, centrifugation, filtration, sedimentation, incineration, ion exchange, ultra filtration, and reverse osmosis for liquid waste; sedimentation, drying, dewatering, dehydration, and incineration for wet solids; and decontamination, compaction, baling, shredding, and incineration for dry solids. Bituminization and cementation are used for stabilizing the LLW.

Concerted efforts by the utilities in source reduction and volume reduction have led to average volumes of DAW that are about one-fifth the volumes produced only a decade ago. By 1992, an average PWR generated about 2,000 $\mathrm{ft}^{3} / \mathrm{y}$ and a BWR about $5,000 \mathrm{ft}^{3} / \mathrm{y}$. Similarly, because of increasing treatment of wet waste, the average volume of wet waste has gone down to about 1,000 $\mathrm{ft}^{3}$ for a PWR and about 4,000 $\mathrm{ft}^{3}$ for a BWR.

Compaction and supercompaction are by far the most widely used techniques to reduce volume of compactible solid waste. Examples of compactible items are plastics, paper, cloth, and other absorbent materials. In fact, plastics and paper account for nearly $70 \%$ of the compacted waste at nuclear power plants; cloth, adsorbent material, rubber, and other miscellaneous materials account for the rest. Noncompactible materials include metal pipes and valves, wood, filters and resins, and miscellaneous items such as glass, tools, and concrete. Wood, pipes, and valves account for nearly $50 \%$ of the noncompactible waste; conduit, filters, concrete, tools, dirt, glass, and other miscellaneous materials account for the rest.

Wet wastes are dewatered using decontamination tanks, centrifuges, dewatering filters, evaporation, or calcination. Then, they are solidified using cement, urea-formaldehyde, bitumen, or organic polymers. Cement can also be used to process the wastes directly without dewatering. Its lowcost, easy availability, and fire resistance make it 
one of the more widely used choices as a solidification agent.

While the liquid effluent releases from power plants have remained approximately constant, the utilities have used extensive treatment methods to separate the radionuclide constituents from the liquid waste. The principal methods for treating liquid wastes involve hold-up tanks (to allow radioactive decay), evaporator systems, ionexchange resins, and filtration systems. The processes can be used individually or sequentially. lon-exchange systems and evaporator systems are widely used in the industry.

\section{Storage}

Solid radioactive wastes are generally stored in specially engineered buildings. The DAW can be stored in stackable metal boxes, wood containers, or 55-gallon drums. As an example, the Cook Plant in Bridgeman, MI, has stored waste on-site since November 1990, when the waste generators in the state of Michigan lost access to licensed disposal sites because of lack of progress by the State in developing its own disposal site. While packaging waste for storage, it is better to adhere to the disposal site acceptance criteria to avoid repackaging when the waste is eventually sent for disposal. For the dewatered resins and filters, the current standard practice for interim storage involves storing them in high-integrity containers (HICs). Solidification of such waste with materials such as cement is another option.

For long-term storage of higher-activity waste, a variety of structures are used on the international scene. These include concrete trenches, cylindrical bunkers, concrete monoliths/radblocks, in-ground storage containers (ISCs), dry storage modules (DSMs), tile holes, and quadricells.

Handling of radioactive materials has to meet the requirements of 10 CFR 20, Standards for Protection Against Radiation. Regulations for storage of waste are also specified in Appendix A of 10 CFR 50, Domestic Licensing of Production and Utilization Facilities, under which the power plants are licensed. The storage facility must meet certain requirements related to the control of radioactive releases to the environment, safety systems, detection of excessive radiation levels, and monitoring of effluents.

\section{Operational Aspects/Health Physics}

Radiation control areas (RCAs) at reactor sites are defined and designated with warning signs and readout devices. Such areas may be designated as radioactive material area, radiation area, high radiation area, very high radiation area, surface contamination area, or airborne radioactive material area. In addition to area designation, sign postings specify the requirements for entering an area, for example, personal monitoring devices required, respiratory protection required, shoe covers required, or signed radiation work permit required.

Radiation Safety Procedure manuals for a nuclear power plant provide health physics guidance to workers. For example, an RCA is defined as an area where an individual could receive a dose of $2 \mathrm{mrem} / \mathrm{h}$ (not to exceed 100 mrem in any seven consecutive days, and not to exceed $125 \mathrm{mrem}$ in any one calendar quarter). Such areas are barricaded and conspicuously posted. Areas where an individual could receive $100 \mathrm{mrem} / \mathrm{h}$ are defined as High Radiation Areas; these are barricaded and appropriately posted. Locked doors are used for any areas where radiation dose could be greater than $1000 \mathrm{mrem} / \mathrm{h}$. Radiation Work Permits are required for entry into any RCA and specific health physics procedures are followed, including personnel monitoring equipment, respiratory protection, and protective clothing, as necessary.

Labels or tags are used to identify specific containers of radioactive material or contaminated objects. Labels or tags must have a magenta radiation symbol (trefoil) on a yellow background. Typically, a label contains the following information: radiation symbol, name of radionuclide, activity ( $\mathrm{Ci}$ or $\mathrm{Bq}$ ) of the material, dose rate at the surface of the container, date, and the initials of person who prepared the label. Labels are also used for localized areas of "fixed" surface contamination and contaminated equipment.

Protective clothing can range from simple gloves to full-body protective suits, and their use will depend on the radiation environment and the type of radioactive waste being handled. Respiratory protection may be required in certain cases. The 
dose accumulated by each worker is monitored. Good records of previous doses are maintained so that worker assignments can take into account such data. For higher-activity waste, worker contact is minimized; remote handling and packaging are necessary in some cases. Hand and shoe monitoring are used to ensure that contamination is not carried away to other areas. At the minimum, the employees are required to have training in radiation protection and in handling radioactive materials. Under the "Hazard Communication" standard (29 CFR 1910.1200) issued by Occupational Safety and Health Administration, the workers must be informed of the hazards of chemicals. These apply to radioactive materials as well. Good planning and scheduling are key to a safe facility operation that complies with the radiation protection requirements. An emergency management plan is also prepared and emergency response is practiced.

\section{Disposal}

In 1992, about 1.7 million cubic feet of LLW with one million curies of activity was received at the three commercial disposal sites: Barnwell, SC; Beatty, NV; and Richland, WA. Barnwell accepted about $48 \%$ of the waste volume with about $82 \%$ of the total activity. The states shipping the largest volumes included: Illinois, Texas, Oregon, California, Pennsylvania, and Virginia. On the basis of total activity shipped, the largest contributing states were Pennsylvania, Illinois, Nebraska, New York, Minnesota, and Massachusetts. A 1992 survey by the National Low-Level Waste Management Program showed that while the nuclear power utilities accounted for about $35 \%$ of total waste volume disposed of at the commercial disposal sites, they accounted for almost $86 \%$ of the curie content.

Currently, only two commercial disposal sites are open in the country (the third, Beatty, NV, is closed). Of these, the Richland, WA, site is now closed to generators outside the Northwest and Rocky Mountain compacts. The Barnwell, SC, site, which has accepted the bulk of the commercial waste in the past, is set to close its doors to out-of-compact waste on June 30, 1994, even though a number of legislative initiatives are currently underway in the state legislature to push this exclusion date to December 1995.
The wastes accepted at Barnwell are solid or solidified waste packaged in steel drums, steel boxes, HICs, or concrete overpacks; no liquids are accepted. The engineered disposal trenches at the site are typically $1000 \mathrm{ft} \times 1000 \mathrm{ft}$ and $22 \mathrm{ft}$ deep. The filled trenches are capped with $2 \mathrm{ft}$ of compacted soil. For most utilities, the access to disposal is dwindling rapidly. With high surcharges, the out-of-compact customers are now paying $\$ 300 / \mathrm{ft}^{3}$ for disposal at Barnwell. However, even this access may not be available in future. Thus, waste source minimization, volume reduction, and expanded on-site storage are becoming a necessity for most utilities.

The shallow ground disposal facilities for LLW are licensed under the provisions of 10 CFR 61, mentioned earlier.

\section{Compacts}

Responsibility for the disposal of commercially generated LLW was shifted to the states by the Low-Level Radioactive Waste Policy Act of 1980 (LLRWPA). The LLRWPA encouraged the states to form regional compacts or to develop their own disposal facilities. The January 1, 1986 was the deadline after which compacts could restrict the use of their disposal facilities by excluding waste generated outside the compact. However, by 1983, it had become clear that no new disposal facilities would be operational by the 1986 milestone. As a result, the Low-Level Radioactive Waste Policy Amendment Act of 1985 (LLRWPAA) was passed by Congress in January 1986. The LLRWPAA extended the January 1 , 1986 deadline by seven years, to January 1 , 1993, and established a series of milestones, penalties, and incentives for regional compacts and states to promote progress toward being able to manage their LLW by 1993. It is 1994 and no new disposal facilities have opened as yet nor are they likely to open in near future.

As of August 1993, the nine regional compacts included the Northeast, Appalachian, Southeast, Central Midwest, Central, Midwest, Northwest, Rocky Mountain, and Southwestern. In addition, several states were unaffiliated: Texas, New York, Michigan, Vermont, New Hampshire, and Maine. Some recent realignments of States (transgressing geographical regions) have led to a changing picture. For example, Maine and Vermont have been accepted by Texas to form a 
new compact.

However, no real progress has been made on disposal facility development and milestones have been frequently postponed. Even the States which had aggressive plans have faltered. For example, in the Central Midwest Compact, a site at Martinsville, in Illinois, proposed by the state's Department of Nuclear Safety was rejected by a Special Siting Commission. The state has legislated new procedures for siting a disposal facility. Thus, the initial schedule of building a facility scheduled for operation in 1995 has been discarded. The only new facility site which appears to be closer to site approval stage is California's Ward Valley. But, here again, the federal government's decision to suspend action on the transfer of federal land to California has stalled the process for the moment.

Problems experienced at past disposal sites (Maxey Flats, KY, West Valley, NY, and Sheffield, IL which at have been closed for many years) have something to do with public attitudes toward acceptance of waste disposal facilities. These problems can be traced to inadequate site characterization and the lack of an integrated approach to waste management and disposal. In addition to a suitable site that offers natural barriers to radionuclide migration, newer waste disposal facility designs rely also on engineered barrier systems. Internationally, several concepts are being studied, such as above-ground vaults (AGVs), below-ground vaults (BGVs), earthmounted concrete bunkers (EMCBs), modular concrete canister disposal (MCCD), and intermediate depth disposal (IDD). For higheractivity waste, greater-confinement-disposal (GCD) has been studied in the United States.

It is clear that the LLRWPA and LLRWPAA have not accomplished what they were intended to do. The siting of disposal facilities has proved to be so contentious that no significant progress has been made. With dwindling access to the only two operating commercial facilities in the country, the nuclear utilities are forced to store more and more waste on-site. It is worth noting that nonutility generators, such as industries using radioisotopes, and medical and academic institutions (which incidentally accounted for about $56 \%$ of the LLW shipped for disposal in 1992), may not even have this on-site storage option. A general attitude of not in my backyard has led to a total paralysis in the development of new waste disposal sites. A sensible approach to national low-level radioactive waste disposal is sorely needed.

\section{CONCLUSION}

Faced with a shortage of pool storage space and the uncertainty in the development of a federal disposal facility at Yucca Mountain, as well as the uncertainty in acceptance of spent fuel by DOE by the scheduled date of January 31, 1998, the nuclear power industry has turned to dry storage of spent fuel.

For LLW, the industry has done an excellent job in waste minimization through source reduction and application of volume reduction technologies. However, with access to commercial disposal sites dwindling and disposal costs escalating, the industry has few optiors except to expand the onsite storage. The Acts passed by Congress that shifted responsibility for disposal of LLW to the states have not accomplished what they were intended to do. Milestones have been repeatedly postponed, and no state compact is closer to opening a new disposal site any time soon.

The technologies for managing the nuclear waste are here and available, but a national will to deal with the tough issue of waste disposal siting is lacking. Consequently, little real progress has been made in the development of disposal facilities for spent fuel or low-level radioactive waste.

\section{BIBLIOGRAPHY}

"1992 State-By-State Assessment of Low-Level Radioactive Wastes Received at Commercial Disposal Sites," Idaho National Engineering Laboratory, EG\&G Idaho, Inc., National Low-Level Waste Management Program, DOE/LLW-181 (September 1993).

"Radwaste Generation Survey Update, Volume 1: Boiling Water Reactors; Volume 2: Pressurized Water Reactors," Electric Power Research Institute report EPRI NP-5526 (February 1988).

Nuclear News, Vol. 36, No. 15, December 1993; Vol. 37, No. 3, March 1994; Vol. 37, No. 7, May 1994. 

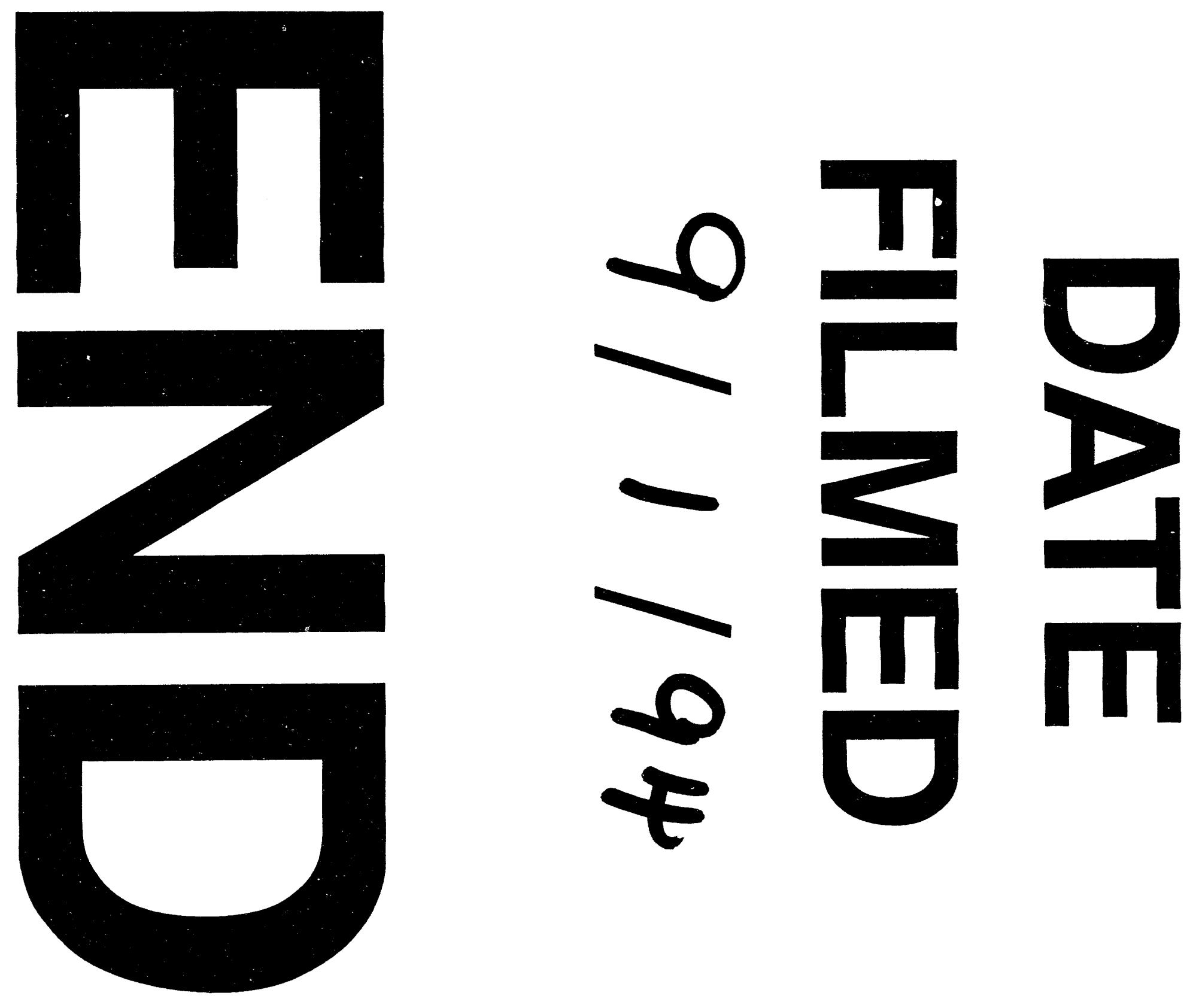
